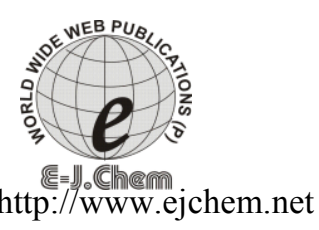

ISSN: 0973-4945; CODEN ECJHAO

E-Journal of Chemistry

2012, 9(2), 962-969

\title{
Synthesis and Characterization of New Amino Acid-Schiff Bases and Studies their Effects on the Activity of ACP, PAP and NPA Enzymes (In Vitro)
}

\author{
ZAHRAA SALIM M. AL-GARAWI, \\ IVAN HAMEED R. TOMI and ALI HUSSEIN R. AL-DARAJI \\ Department of Chemistry, College of Sciences \\ University of Al-Mustansiriya, Baghdad, Iraq \\ ivanhrtomy@yahoo.com
}

Received 17 October 2011; Accepted 30 December 2011

\begin{abstract}
In this study, two new Schiff base compounds derived from the condensation reaction of $L$-glycine and $L$-tryptophan with 4-methylbenzaldehyde have been synthesized. The Schiff base compounds were characterized by FT-IR, UV and ${ }^{1} \mathrm{H}$ NMR spectroscopy. Their effects on the activity of total (ACP), prostatic (PAP) and non prostatic (NPA) acid phosphatase enzymes were studied. The Schiff base derived from $L$-glycine (A) demonstrated inhibition effect on the ACP and NPA activities and activation effect on PAP activity. The Schiff base derived from $L$-tryptophan (B) demonstrated semi fixed inhibition effects on the ACP and NPA activities at high concentrations $\left(5.5 \times 10^{-2}, 5.5 \times 10^{-3}\right.$ and $\left.5.5 \times 10^{-4} \mathrm{M}\right)$ and activator effect at low concentration $\left(5.5 \times 10^{-5} \mathrm{M}\right)$ while it was exhibits as activator on PAP activity.
\end{abstract}

\section{Introduction}

Schiff bases are the compounds containing azomethin group $(-\mathrm{HC}=\mathrm{N}-)$. They are condensation products of ketones or aldehydes with primary amines. Formation of Schiff base generally takes place under acid or base catalysis or with heat. Schiff-bases are considered as a very important class of organic compounds and have a wide application in many biological aspects, proteins, visual pigments, enzymatic aldolization and decarboxylation reactions ${ }^{1}$. Moreover, some Schiff-bases were exhibits antibiotic, antiviral and antitumor agents because of their specific structure ${ }^{2}$.

Acid phosphatase (ACP) is a type of enzyme manufactured by the body. It is classified as a hydrolase enzyme. Specifically, acid phosphatase targets and breaks the molecular bonds of phosphate groups ${ }^{3}$. Generally speaking, ACP can be found in certain organs and tissues, including blood cells, bone marrow, spleen, pancreas, liver, and kidneys ${ }^{4}$. However, this substance is found in the greatest concentration in the prostate and up to 1,000 times greater in seminal fluid than any other bodily fluids. Prostatic acid phosphatase (PAP) is an enzyme 
produced by the prostate. Its evaluated in prostate cancer. The highest levels of acid phosphatase are found in metastasized prostate cancer, while diseases of the bone, such as Paget's disease or hyperparathyroidism, diseases of blood cells, such as sickle-cell disease or multiple myeloma or lysosomal storage diseases, such as Gaucher's disease, will show moderately increased levels ${ }^{5}$.

Schiff bases appear to be an important intermediate in a number of enzymatic reactions involving interaction of an enzyme with an amino or a carbonyl group of the substrate. One of the most important types of catalytic mechanism is the biochemical process which involves the condensation of a primary amine in an enzyme usually that of a lysine residue, with a carbonyl group of the substrate to form an imine, or Schiff base ${ }^{6}$.

There are many interesting studies on the Schiff bases compounds derived from amino acids. Matharasi et $a l^{7}$ found that the Schiff bases derived from amino acid and Aloin [the bio active molecule, 10-glucopyranosyl-1,8-dihydroxy-3-(hydroxylmethyl)-9, (10H) anthracenone] having good antibacterial activity in good range when comparison to control (Ampicilin). Also Deng et $\mathrm{al}^{8}$ synthesized a new derivative of amino acids azomethin and its complexes with tin that it used in biological activates. The 2-acetyl-benzimidazoledehydeglycine Schiff base ligand and the corresponding Pr (III) complexes were synthesized and their fluorescent properties studied by Danghui et al ${ }^{9}$. Also, the Schiff bases compounds derived from amino acids were used as a ligands and their complexes were used in wide range in medicinal chemistry ${ }^{10-12}$.

The aim of the present work is to studying the effect of Schiff base compounds derived from $L$-glycine and $L$-tryptophan on the activity of acid phosphatase enzymes, where no similar researches found in the literature. These products might be potential compounds for biological activity tests on this enzyme.

\section{Experimental}

All starting materials and solvents were purchased from Aldrich and Fluka and used without further purification. Melting points were determined on Electrothermal capillary apparatus and are uncorrected, FT-IR measurements were recorded on Shimadzu model FTIR-8400S. ${ }^{1} \mathrm{H}$ NMR spectra were obtained with Bruker spectrophotometer model ultra shield at $300 \mathrm{MHz}$ in DMSO- $\mathrm{d}_{6}$ solution with the TMS as internal standard. UV-Vis spectra and the enzyme activity for the compounds were measured at room temperature by using (UV-Vis) spectrophotometer type Shimadzu. Acid phosphatase kit (total and prostatic) was made in Linear chemicals S. L. company (kinetic method type) Note: in some ${ }^{1} \mathrm{H}$ NMR spectra, the peaks at $\delta 2.5$ and 3.35 are for the solvent $\left(\mathrm{DMSO}-\mathrm{d}_{6}\right)$ and dissolved water in $\left(\mathrm{DMSO}-\mathrm{d}_{6}\right)$ respectively.

\section{Preparation method of amino acids Schiff bases $A \& B$}

The Schiff bases derived from 4-methylbenzaldehyde and L-amino acids were prepared using a method similar to one given in the reference ${ }^{13}$. To a solution of 4-methylbenzaldehyde $(0.144 \mathrm{~g}, 1.2 \mathrm{mmol})$ in methanol $(10 \mathrm{~mL})$, L-amino acid $(1.0 \mathrm{mmol})$ in methanol $(15 \mathrm{~mL})$ containing potassium hydroxide $(0.056 \mathrm{~g}, 1.0 \mathrm{mmol})$ was added. The obtained solution was then magnetically stirred for $8 \mathrm{~h}$ at $50-60^{\circ} \mathrm{C}$ in water bath. The volume of the obtained brownish red solution was reduced in vacuum using a rotary evaporator and then washed with absolute ethanol. Anhydrous diethyl ether was added to wash the products at room temperature and then dried in air for $2 \mathrm{~h}$. The physical properties and FT-IR data for Schiff bases derivatives are listed in Table 1. ${ }^{1} \mathrm{H}$ NMR (A): (DMSO- $\left.d_{6}, 300 \mathrm{MHz}, \delta, \mathrm{ppm}\right)$ $11.23,8.11,6.88-7.90,2.33,2.05$; (B): (DMSO- $\left.d_{6}, 300 \mathrm{MHz}, \delta, \mathrm{ppm}\right) 11.34,8.03,6.73-$ $7.91,3.09,2.31,2.02$. 
Table 1. Physical, FT-IR and electronic spectral data of compounds A and B.

\begin{tabular}{|c|c|c|c|c|c|c|c|c|c|}
\hline \multirow[b]{2}{*}{ Comp. } & \multicolumn{3}{|c|}{ Physical properties } & \multicolumn{5}{|c|}{ FT-IR spectral data } & \multirow{2}{*}{$\begin{array}{c}\text { Electronic } \\
\text { data, } \\
\lambda_{\max } / \mathrm{nm}\end{array}$} \\
\hline & $\begin{array}{l}\text { Empirical } \\
\text { formula }\end{array}$ & $\begin{array}{c}\text { Yield } \\
\%\end{array}$ & $\begin{array}{c}\mathrm{Mp}, \\
{ }^{\circ} \mathrm{C}\end{array}$ & v O-H & $v \mathrm{C}=\mathrm{C}$ & $\begin{array}{c}v \\
\mathrm{CH}=\mathrm{N}\end{array}$ & v $\mathrm{C}=\mathrm{O}$ & $\begin{array}{l}\text { v C-H } \\
\text { aliph }\end{array}$ & \\
\hline A & $\mathrm{C}_{10} \mathrm{H}_{11} \mathrm{NO}_{2}$ & 70 & * & 3256 & $\begin{array}{l}1587, \\
1514\end{array}$ & 1652 & 1707 & $\begin{array}{l}2949, \\
2850\end{array}$ & 256,212 \\
\hline B & $\mathrm{C}_{19} \mathrm{H}_{18} \mathrm{~N}_{2} \mathrm{O}_{2}$ & 77 & $88-90$ & 3259 & $\begin{array}{l}1589, \\
1515\end{array}$ & 1641 & 1709 & $\begin{array}{l}2056, \\
2862\end{array}$ & 258,220 \\
\hline
\end{tabular}

\section{Materials and methods of biological activity section}

The method ${ }^{14,15}$ is based on the hydrolysis of $\alpha$-naphtyl phosphate at $\mathrm{pH} 5.2$ by acid phosphatase (ACP) to produce $\alpha$-naphtol and inorganic phosphate. The pentanediol acts as phosphate acceptor increasing the reaction sensitivity.

The $\alpha$-naphtol reacts with fast Red TR, to produce a coloured complex directly proportional to the activity of ACP in the sample. $\alpha$-naphthylphosphate is hydrolyzed by serum acid phosphatase to a-napthol and inorganic phosphate. The rate of hydrolysis is proportional to the enzyme acitivity present. The $\alpha$-naphthol produced is coupled with Fast Red TR to produce a colored complex which absorbs light at $405 \mathrm{~nm}$. The reaction can be quantitated photometrically because the coupling reaction is instantaneous. $L$-Tartrate inhibits prostatic acid phosphatase but does not interfere with the reaction mechanism. Therefore, if testing is performed in the presence and in the absence of $L$-Tartrate, the difference between the results of the two assays is the level of prostatic acid phosphatase in the serum.

$$
\begin{gathered}
\alpha \text {-naphtyl phosphate }+\mathrm{H}_{2} \mathrm{O} \underset{\mathrm{pH} 5.0}{\alpha \text {-naphtol }}+\text { Fast Red TR } \underset{30-37^{\circ} \mathrm{C}}{\longrightarrow} \text { Azophtol dye }
\end{gathered}
$$

A stock solution ( $5.5 \mathrm{mmol}$ ) of compounds A and B were prepared by dissolving these compounds in buffer solution of ACP kit (Sodium citrate $110 \mathrm{mmol} / \mathrm{L}, 1,5$-pentanediol $220 \mathrm{mmol} / \mathrm{L}, \mathrm{pH} 5.2)$ and the following concentrations $\left(5.5 \times 10^{-2}, 5.5 \times 10^{-3}, 5.5 \times 10^{-4}, 5.5 \times 10^{-5}\right.$ mmol) were prepared by diluting with the same buffer. The ACP and NPA activities of a healthy subject ( 21 years old) were determined. The inhibition and activation percentage were calculated by comparing the activity with and without the Schiff base compounds under the same enzymatic reaction by replacing $100 \mu \mathrm{L}$ of buffer with $100 \mu \mathrm{L}$ of $\mathrm{A}$ and $\mathrm{B}$ solutions, according to the equation:

$\%$ Inhibition $=100-100 \times($ The activity in the presence of inhibitor) $/$ (The activity in the absence of inhibitor). The activation percentage was calculated by comparing the activity with and without the activator and under the same conditions, according to the equation: \% Activation $=100 \times$ (The activity in the presence of activator) $/$ (The activity in the absence of activator) -100 . The activity of PAP enzyme was calculated by the following equation: Activity of PAP enzyme = activity of ACP enzyme - activity of NPA enzyme

\section{Results and Discussion}

\section{Synthesis}

The condensation of 4-methylbenzaldehyde and $L$-amino acids in methanol gives the products $\mathrm{A}$ and $\mathrm{B}$ according to the following reaction: 

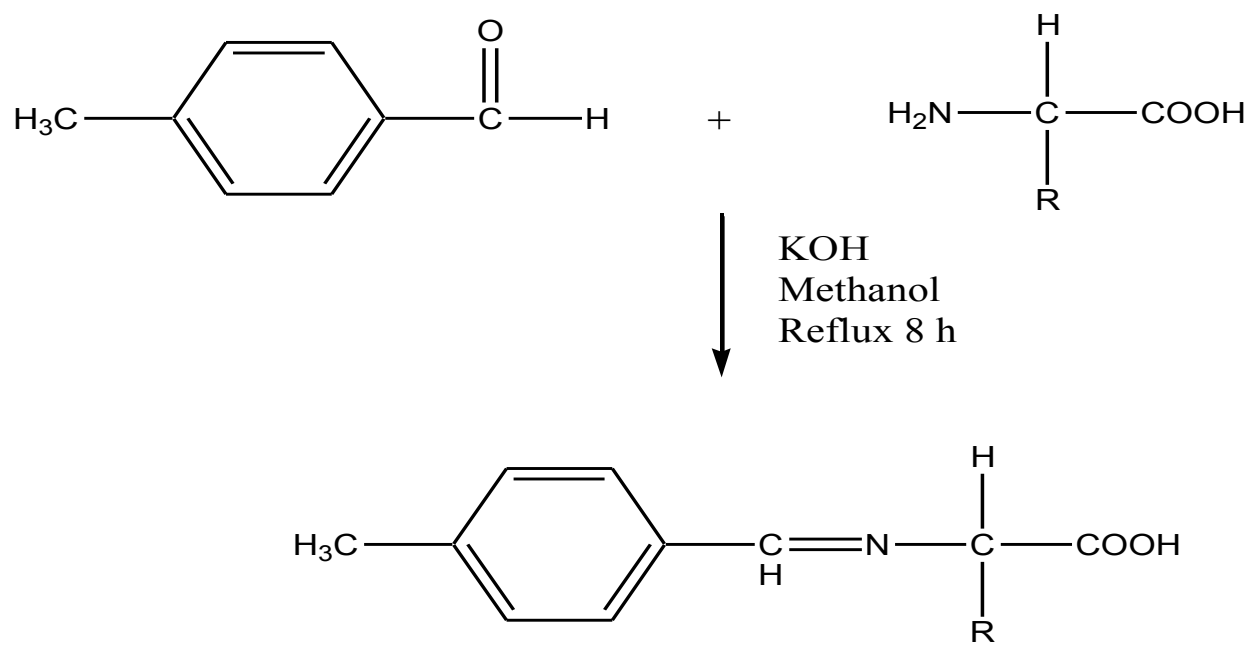

$\mathrm{R}=\mathrm{H} \quad$ compound $\mathrm{A}$

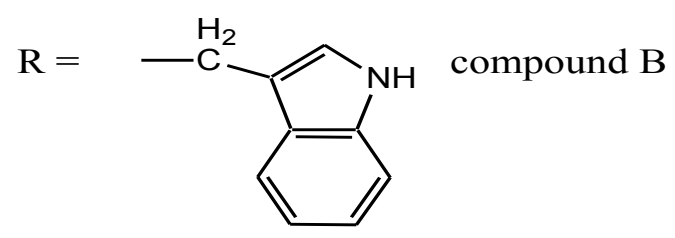

The physical, FT-IR and electronic spectral data of these compounds are listed in Table 1. These compounds are soluble in methanol, ethanol and other polar solvents. The strong absorption bands near 1585 and $1515 \mathrm{~cm}^{-1}$ are attributed to the ring $\mathrm{C}=\mathrm{C}$ stretching bands. The azomethin stretching bands is observed near $1650 \mathrm{~cm}^{-1}$. Also the bands near $1707 \mathrm{~cm}^{-1}$ are assigned to the carbonyl stretching band while the bands near $3255 \mathrm{~cm}^{-1}$ are attributed to the hydroxyl group of acid for Schiff bases compounds $\mathrm{A}$ and $\mathrm{B}$.

The ${ }^{1} \mathrm{H}$ NMR spectrum of Schiff base compound A, Figure 1, exhibits singlet signals at 11.23 and $8.11 \mathrm{ppm}$, attributed to $\mathrm{CH}=\mathrm{N}$ and $\mathrm{COOH}$ protons respectively ${ }^{16}$. The multi signals within the $6.88-7.90 \mathrm{ppm}$ range are assigned to the aromatic protons of benzene ring. The two signals at 2.33 and $2.05 \mathrm{ppm}$ are assigned to the $\mathrm{CH}_{2}$ and $\mathrm{CH}_{3}$ groups respectively.

The ${ }^{1} \mathrm{H}$ NMR spectrum of Schiff base compound B, Figure 2, is consistent with the proposed structure. The peak at $11.34 \mathrm{ppm}$ (singlet) corresponds to the carboxylic acid proton and the one at $8.03 \mathrm{ppm}$ corresponds to the proton of the azomethin group. Moreover, the triplet at 2.31, doublet at 3.09 and singlet at $2.02 \mathrm{ppm}$ are assigned to the protons of $\mathrm{CH}$, $\mathrm{CH}_{2}$ and $\mathrm{CH}_{3}$ groups respectively. The peaks around 6.73-7.91 ppm corresponds to the aromatic protons in the molecule within the $\mathrm{NH}$ proton of indole ring. 


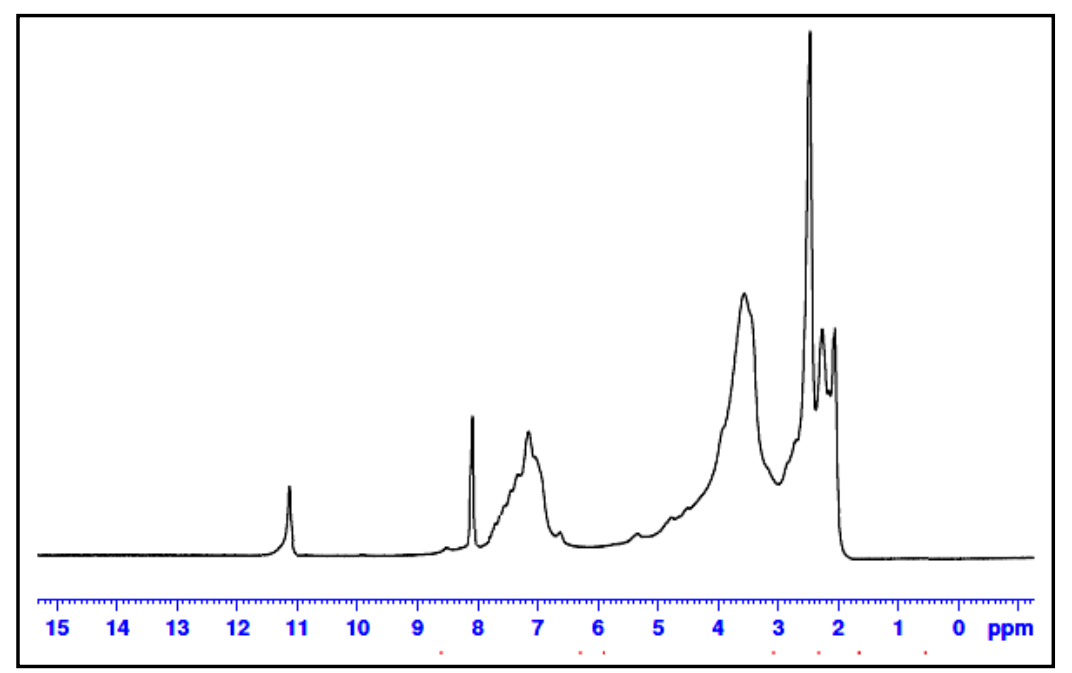

Figure $1{ }^{1} \mathrm{H}$ NMR spectrum of compound A.

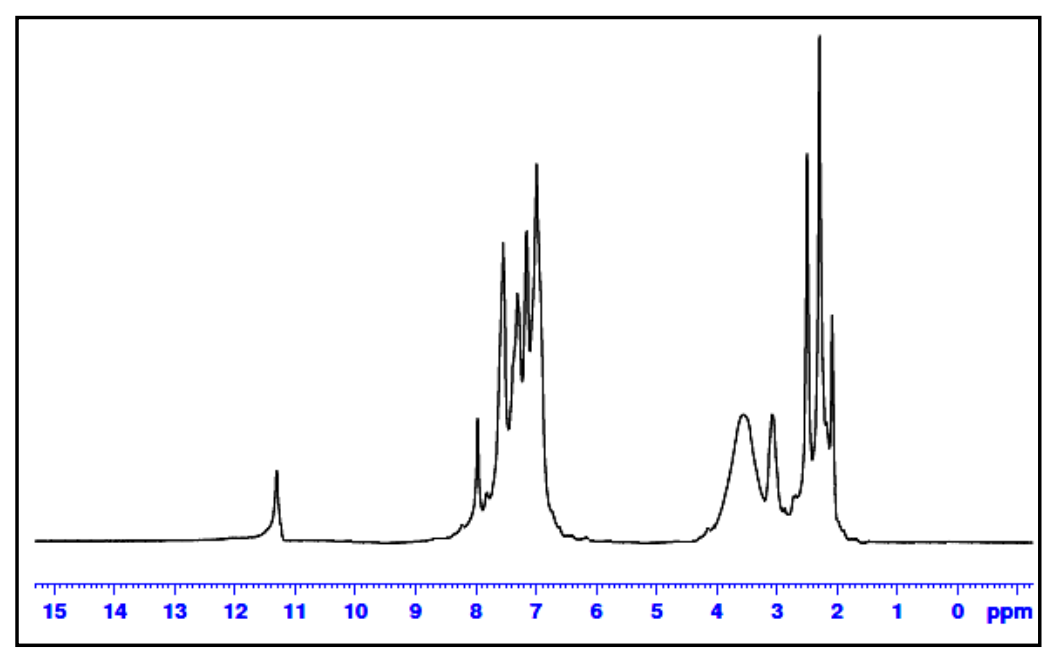

Figure 2. ${ }^{1} \mathrm{H}$ NMR spectrum of compound B.

\section{Biological activity of compounds $A$ and $B$ on ACP, PAP and NPA enzymes}

This work addresses investigation of the effect of compounds A and B on ACP, PAP and NPA enzymes. The biochemical tests revealed that these compounds caused inhibition and activation of these enzymes activities. Table 2 and 3 shows the effect of different concentrations of compound A and B on the activities of ACP, PAP and NPA enzymes in a human serum. The normal values of ACP, PAP and NPA enzymes activities were 4.80, 0.30 and $4.50 \mathrm{U} / \mathrm{L}$ respectively. The relationship between the concentrations of compound $\mathrm{A}$ and the activity of enzymes ACP, PAP and NPA were shown in Figure 3 while Figure 4 shows the relationship between enzymes activity and compound $\mathrm{B}$ concentrations. We suggested that compounds $\mathrm{A}$ and $\mathrm{B}$ molecules have $(\mathrm{N}$ - and $\mathrm{O}=)$ group which interact with active sides of these enzymes. 
Table 2. The effect of different concentrations of compound A on the activity of ACP, PAP and NPA enzymes.

\begin{tabular}{lcccc}
\hline Enzyme & Conc. M & Activity U/L & Activation \% & Inhibition \% \\
\hline ACP & 0 & 4.80 & - & - \\
& $5.5 \times 10^{-2}$ & 1.30 & - & 72.92 \\
& $5.5 \times 10^{-3}$ & 1.70 & - & 64.58 \\
& $5.5 \times 10^{-4}$ & 2.70 & - & 43.75 \\
PAP & $5.5 \times 10^{-5}$ & 2.50 & - & 47.92 \\
& 0 & 0.30 & - & - \\
& $5.5 \times 10^{-2}$ & 0.30 & 0.00 & - \\
& $5.5 \times 10^{-3}$ & 0.30 & 0.00 & - \\
NPA & $5.5 \times 10^{-4}$ & 0.30 & 0.00 & - \\
& $5.5 \times 10^{-5}$ & 0.80 & 166.67 & - \\
& 0 & 4.50 & - & - \\
& $5.5 \times 10^{-2}$ & 1.00 & - & 77.78 \\
& $5.5 \times 10^{-3}$ & 1.40 & - & 68.89 \\
& $5.5 \times 10^{-4}$ & 2.40 & - & 46.67 \\
& $5.5 \times 10^{-5}$ & 1.70 & - & 62.22 \\
\hline
\end{tabular}

Table 3. The effect of different concentrations of compound B on the activity of ACP, PAP and NPA enzymes.

\begin{tabular}{lcccc}
\hline Enzyme & Conc. M & Activity U/L & Activation \% & Inhibition \% \\
\hline ACP & 0 & 4.80 & - & - \\
& $5.5 \times 10^{-2}$ & 2.50 & - & 47.91 \\
& $5.5 \times 10^{-3}$ & 2.50 & - & 47.91 \\
& $5.5 \times 10^{-4}$ & 2.80 & - & 41.67 \\
PAP & $5.5 \times 10^{-5}$ & 10.80 & 125.00 & - \\
& 0 & 0.30 & - & - \\
& $5.5 \times 10^{-2}$ & 0.30 & 0.00 & - \\
& $5.5 \times 10^{-3}$ & 0.30 & 0.00 & - \\
NPA & $5.5 \times 10^{-4}$ & 0.30 & 0.00 & - \\
& $5.5 \times 10^{-5}$ & 4.90 & 1533.33 & - \\
& 0 & 4.50 & - & - \\
& $5.5 \times 10^{-2}$ & 2.20 & - & 51.11 \\
& $5.5 \times 10^{-3}$ & 2.20 & - & 51.11 \\
& $5.5 \times 10^{-4}$ & 2.50 & - & 44.44 \\
\hline
\end{tabular}

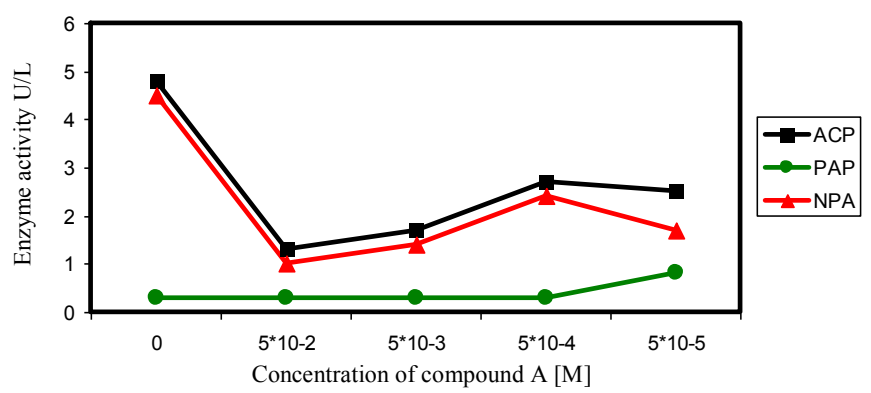

Figure 3. The levels of ACP, PAP and NPA enzymes in the presence of different concentrations of compound A. 


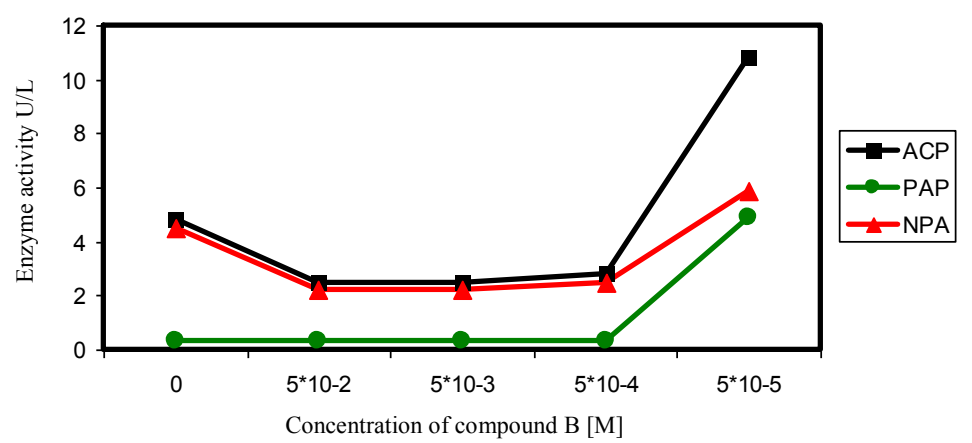

Figure 4. The levels of ACP, PAP and NPA enzymes in the presence of different concentrations of compound $\mathrm{B}$.

Tables 2 and 3 show some important results: $1^{\text {st }}$; compound A inhibit the activity of ACP and NPA while it exhibits as activator on PAP enzyme activity. $2^{\text {nd }}$; compound B shows inhibition and activation of all enzymes activity, these results depending on the concentration of compound B. $3^{\text {rd }}$; the activity of the ACP and NPA increasing when the concentration of the compound A increased. The derivative B showed potent activation of the PAP at low concentration $\left(5.5 \times 10^{-5}\right)$, whereas it showed good activation of ACP and NPA only at the low concentrations. Thus, it is concluded from the screening results that the derivatives $\mathrm{A}$ and $\mathrm{B}$ have good activation and inhibition effects on the activity of these enzymes.

\section{Conclusion}

Two Schiff base compounds A and B derived from glycine and tryptophan were prepared and structurally characterized using spectroscopic techniques (FT-IR, ${ }^{1} \mathrm{H}$ NMR and UV-Vis). The synthetic route started from the reaction of these amino acids with 4-methyl benzaldehyde in alkali absolute methanol. The Schiff base compounds were prepared to check the effects on the ACP, PAP and NPA enzymes. The biochemical studies revealed that the derivative A caused activation effects on PAP enzyme activity and inhibition effects on ACP and NPA enzyme activities while the derivative B caused activation and inhibition effects on these enzymes depending on its concentration.

\section{Acknowledgment}

We thank Mr. Mohanad H. M. Masad (Al al-Bayt University, Jordan) for helpful about doing the ${ }^{1} \mathrm{H}$ NMR spectra and thermal analysis and Mrs. Zainab K. M. Jawad (Al-Mustansiriya University; College of Science; Department of Chemistry) about doing the FT-IR and electronic spectra. Also we are very grateful to department of chemistry, College of Science, Al-Mustansiriya University for supplying us with some chemicals.

\section{References}

1. Sahoo S K, Bera R K, Baral M and Kanungo B K, J Photochem Photobiology A: Chem., 2007, 188, 298-310.

2. Parekh H M and Patel M N, Russian J Coord Chem., 2006, 32, 431-436 (2006)

3. Raghav N, Mamta, Suman, Anita, Ravinder, Priyanka, International J Appl Biology Pharm Technol., 2010, I, 1011-1015. 
4. Kwok-Wai L, Chin-Yang L, Lung T Y, Tsieh S, Gregory L and Steve Z, Improved immunohistochemical detection of prostatic acid phosphatase by a monoclonal antibody. The Prostate, 1989, 15, 13-21.

5. Nair R R and Johnson, J. K, Advanced Biotech Nov., 2008, 22-32.

6. Arulmurugan S, Kavitha H P and Venkatraman B R, Rasayan J Chem., 2010, 3, 385-410.

7. Matharasi D S P, Abu-Yousef I A, Kumar S G S, Vijayakumar B, Kanan S, Gunasekar C and Narasimhan S, Eur J Sci Res., 2010, 43, 297-306.

8. $\quad$ Deng C, Lin Z, Yang M and Xu B, Adv Mater Res., 2011, 8, 201-203.

9. Danghui W, Yixin Y, Yiqin Y, Tiancheng Z, Xing W, Shaokang W, Yao H and Weizong C, Chin Sci Bull., 2006, 51, 785-790.

10. Panchal P K, Parekh H M, Pansuriya. B, Patel M N, J Enzyme Inhibition Med Chem., 2006, 21, 203-209.

11. Chohan Z H, Arif M, Akhtar M A and Supuran C T, Bioinorg Chem Appl., 2006, 2066, 1-13.

12. Koh L L, Ranford J O, Robinson W T, Svensson J O, Tan A L and Wu D, Inorg Chem., 1996, 35, 6466-6472.

13. Nair M S and Joseyphus R S, Spectrochimica Acta Part A: Molecular and Biomolecular Spectroscopy, 70, 749-753 (2008)

14. Lorentz K, Clin Chim Acta, 2002, 326, 69-80 (2002)

15. Fabiny-Byrd D L and Ertingshausen G, Kinetic method for determining acid Phosphatase activity in serum with use of the "Centrifi Chem" Clinical Chemistry, 1972, 18, 841-844.

16. Boraei A A A, Synthe React Inorg Metal-Org Chem., 2002, 32, 291-304. 


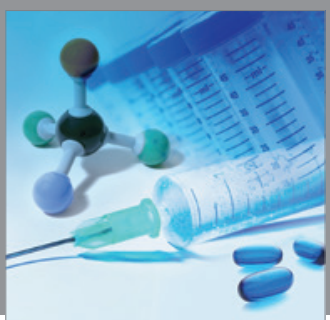

International Journal of

Medicinal Chemistry

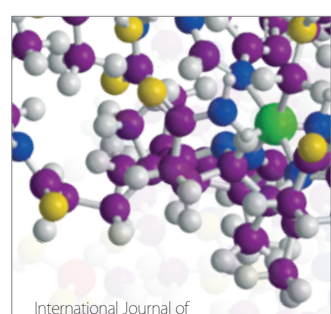

Carbohydrate Chemistry

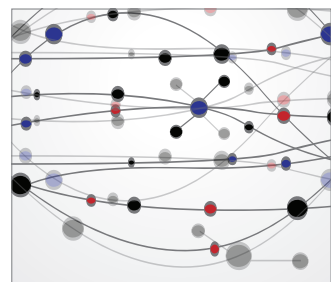

The Scientific World Journal
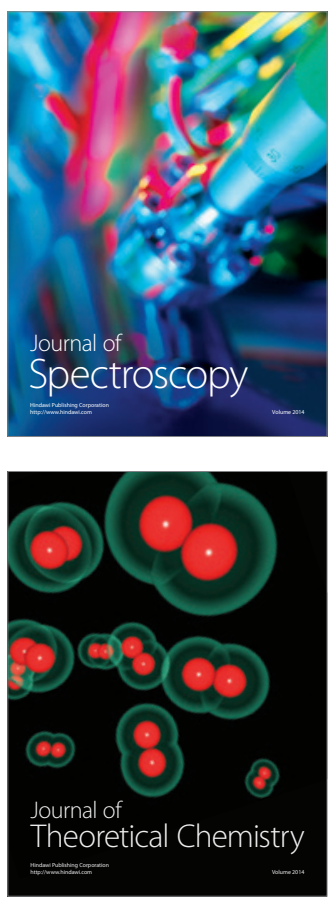
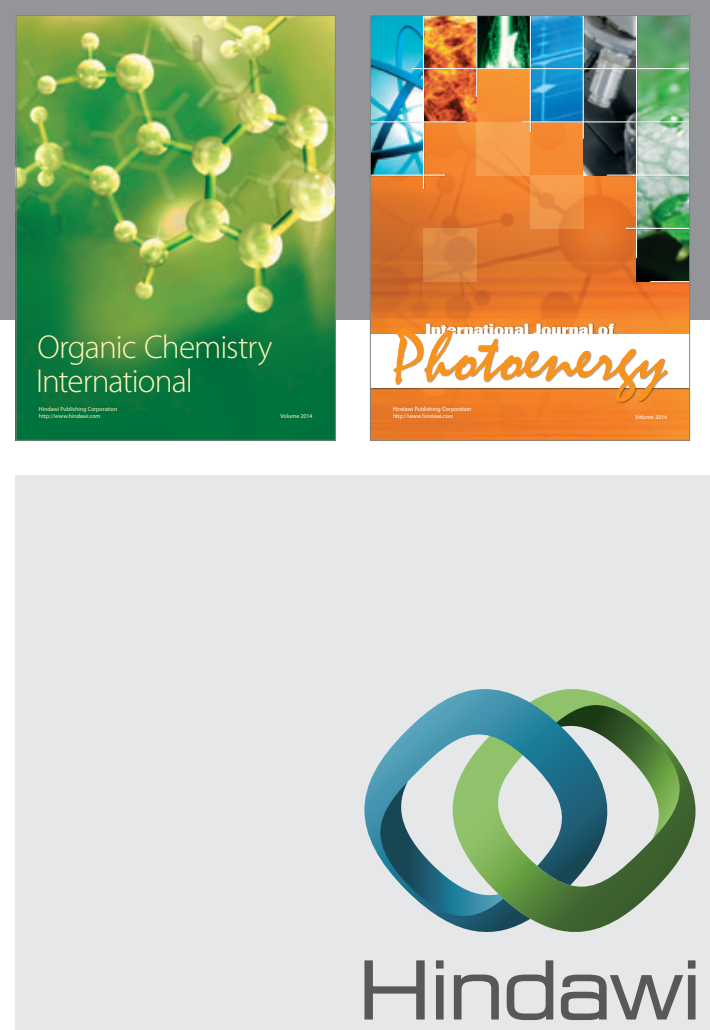

Submit your manuscripts at

http://www.hindawi.com
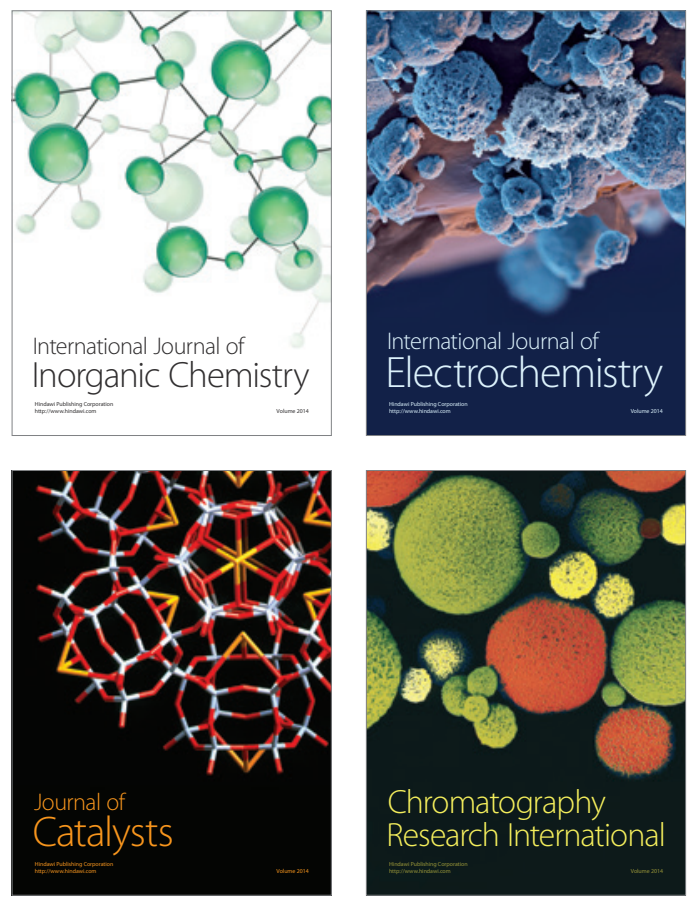
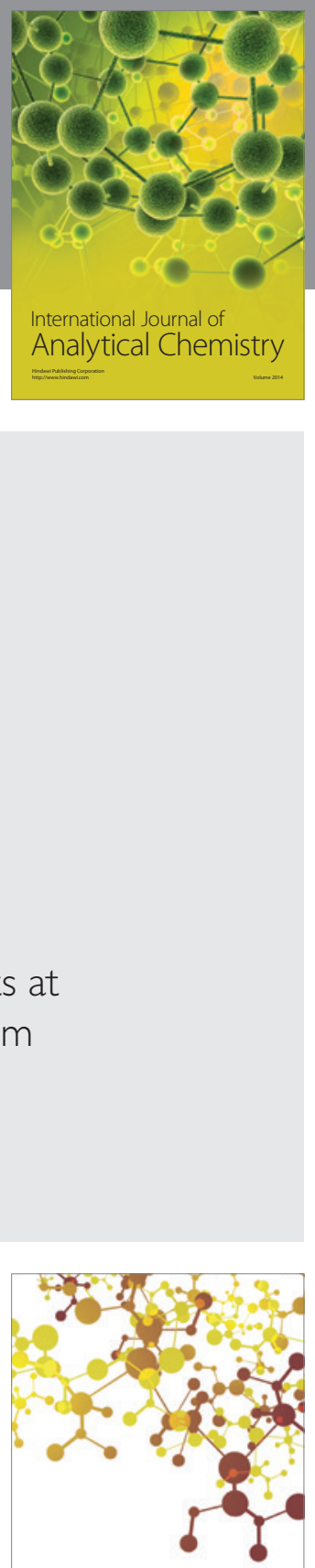

Journal of

Applied Chemistry
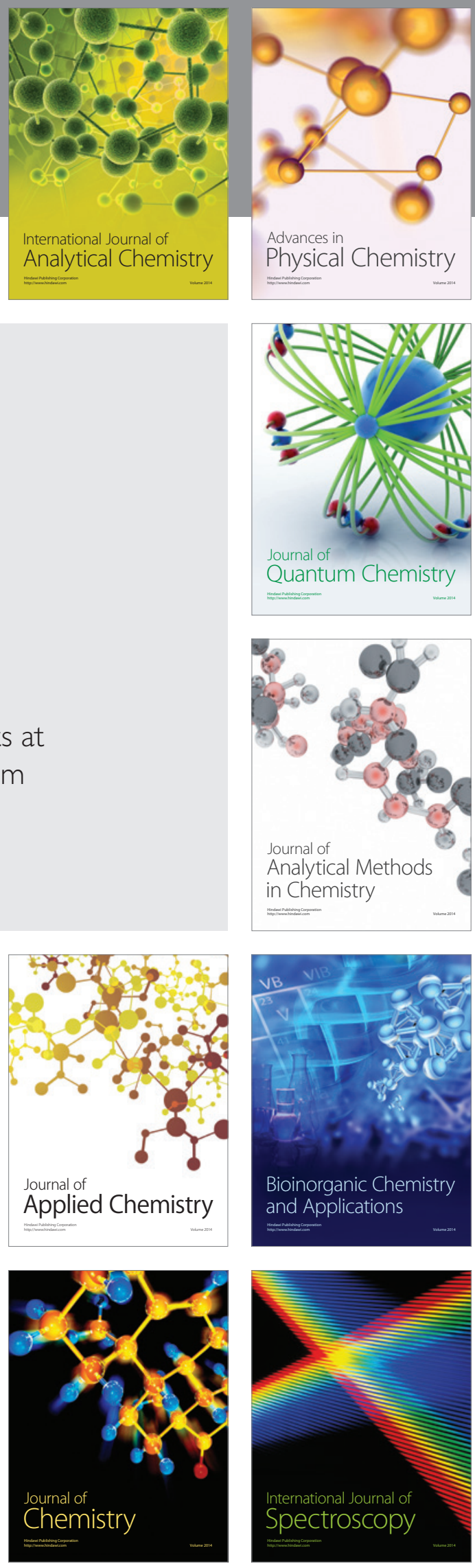